\title{
A tecnificação do campo nos municípios goianos do agronegócio
}

\author{
The technification of the field in the goian municipalities of agribusiness \\ La tecnificación del campo en los municipios de agronegocios de Goiás
}

Recebido: 1409/2021 | Revisado: 22/09/2021 | Aceito: 05/10/2021 | Publicado: 09/10/2021

ORCID: https://orcid.org/0000-0002-6682-3750 Instituto Federal de Educação, Ciência e Tecnologia Goiano, Brasil E-mail: Jesiel.souza@ifgoiano.edu.br

\begin{abstract}
Resumo
A configuração territorial e espacial existente no sudoeste do estado de Goiás é resultado das inúmeras transformações históricas ocorridas na microrregião ao longo do tempo. A partir da produção em escala no Sudoeste de Goiás, dois municípios se transformam nas principais áreas do agronegócio goiano. Pautado em três principais complexos agroindustriais: grãos, carne e sucroenergético. Este artigo busca analisar as transformações ocorridas no sudoeste de Goiás nos últimos anos, sobretudo os municípios de Jataí e Rio Verde e os principais elementos que os transformaram nos principais municípios do agronegócio goiano. Ao mesmo tempo observa-se o agravamento dos problemas socioeconômicos e ambientais mostrados por meio da concentração fundiária, do inchamento das cidades, da exclusão de grupos de pequenos agricultores das áreas-alvo da grande produção, em detrimento de grupos de médios e grandes. Palavras-chave: Modernização agrícola; Sudoeste de Goiás; Agronegócio.
\end{abstract}

\begin{abstract}
The territorial and spatial configuration existing in the southwest of the state of Goiás is the result of the numerous historical transformations that have occurred in the micro-region over time. From the production in scale in the Southwest of Goiás, three municipalities become the main areas of agribusiness in Goiás. Guided in three main agroindustrial complexes: grains, meat and sugar-energy. This article analyzes the transformations that occurred in the southwest of Goiás in recent years, especially the municipalities of Jataí and Rio Verde, and the main elements that transformed them in the main municipalities of the agribusiness of Goiás. At the same time the aggravation of the socioeconomic and environmental problems shown by concentration of land, the swelling of cities, the exclusion of groups of small farmers from the target areas of large production, to the detriment of middle and large groups, is observed.
\end{abstract}

Keywords: Agricultural modernization; Southwest of Goiás; Agribusiness.

\section{Resumen}

La configuración territorial y espacial existente en el suroeste del estado de Goiás es el resultado de las innumerables transformaciones históricas que se han producido en la microrregión a lo largo del tiempo. De la producción a escala en el suroeste de Goiás, dos municipios se convierten en las principales áreas de agronegocios en Goiás. Basado en tres complejos agroindustriales principales: cereales, carne y azúcar-energía. Este artículo busca analizar los cambios que se han producido en el suroeste de Goiás en los últimos años, especialmente los municipios de Jataí y Río Verde y los principales elementos que los transformaron en los principales municipios de la agroindustria en Goiás. Al mismo tiempo, se observan los problemas socioeconómicos y ambientales que muestra la concentración de la propiedad de la tierra, el hinchamiento de las ciudades, la exclusión de grupos de pequeños agricultores de las áreas objetivo de gran producción, en detrimento de los grupos medianos y grandes.

Palabras clave: Modernización agrícola; Al suroeste de Goiás; Agroindustria.

\section{Introdução}

No Cerrado, a modernização agrícola foi progressiva e pontual, ocorrendo principalmente nos territórios onde as atividades agrícolas se reorganizam sob os imperativos do mercado global, principalmente pelas viabilidades do meio técnicocientífico-informacional, incorporando uma racionalidade capitalista nas relações de produção. Antes deste período de transformações, plantavam-se onde e em períodos que a terra permitia, mas com a modernização agrícola pautada na ciência, tecnologia e informação, plantam-se onde e quando convém, respeitando infimamente as leis da natureza, criando, assim, um novo uso do território (Matos; Pessoa, 2009). 
Para Graziano Neto (1982, p. 27), a modernização agrícola é "o processo de transformação capitalista da agricultura que corre vinculado às transformações gerais da economia brasileira recente”. Mendonça (2002) destaca que a modernização conservadora da agricultura - excludente e concentradora - faz parte de um processo de mudança na lógica de produção e reprodução capitalista, e carrega consigo as contradições inerentes ao modo de produção.

As inovações tecnológicas cada vez mais instigam a produção agrícola para que se torne menos dependente da natureza, pois, com o uso da técnica, subordina a natureza ao capital, reproduzindo, de forma artificial, as condições necessárias para a obtenção de uma verdadeira produção agrícola (MATOS; PESSOA, 2009).

Sendo o ecossistema que cobre um quarto do território brasileiro, o Cerrado é o bioma mais ameaçado com o avanço do agronegócio (Canuto, 2004). A principal área de Cerrado no Brasil encontra-se na região Centro-Oeste, e possui “características naturais em termos de relevo, temperatura, precipitações e exposição ao sol muito favoráveis ao desenvolvimento do agronegócio" (Guanziroli, 2006, p. 37).

Mas sem a implementação de políticas específicas que permitam preparar a região para a modernização agrícola, tais características não são suficientes para garantir o desenvolvimento espontâneo da agricultura na região. Assim, é preciso constituir solos aptos à soja, substituindo-os por solos com níveis de acidez aceitáveis, além de adaptar os cultivares de soja às condições tropicais e gerar uma estrutura fundiária capaz de abrigar o novo modelo de produção.

O Cerrado, antes caracterizado pelo sistema de uso múltiplos dos recursos naturais e de uma riqueza biológica, já habitado por uma população diversa camponesa (indígenas, afrodescendentes, geraizeiros, caatingueiros, vazanteiros e retireiros), foi homogeneizado com a chegada da monocultura. A rica diversidade cultural e biológica ali existente tem se transformado em área de expansão da grande propriedade e lavoura "pelas enormes vantagens que oferece, seja pela riqueza hídrica que abriga [...] pela topografia plana de suas chapadas e de seus chapadões" (Porto Gonçalves, 2004, p. 20).

O Estado sempre esteve presente nestes territórios, sobretudo através das políticas públicas, direcionando as vias de desenvolvimento e de sua ocupação. Para Raffestin (1993, p. 15) "de fato o Estado está sempre organizando o território nacional por intermédio de novos recortes, de novas implantações e de novas ligações".

$\mathrm{O}$ investimento em tecnologia, ao mesmo tempo em que levou ao aumento da produtividade, provocou um significativo aumento do preço da terra. Sobre a questão, Mendonça $(2004$, p. 6) atenta para o fato de que as pesquisas "possibilitaram o surgimento de um aparato técnico e científico cada vez mais eficiente, além das inovações tecnológicas específicas para a agropecuária, com destaque para as áreas de fronteira, no caso, o Centro-Oeste brasileiro".

Assim, a tecnologia passa a auxiliar o ritmo da produção agropecuária, que passa a ser cada vez mais moderna, com pivôs de irrigações; máquinas agrícolas utilizadas no preparo do solo, no plantio, nas pulverizações; galpões de armazenamentos; caminhões graneleiros e bitrens levando insumos a propriedades e produtos agrícolas às indústrias; e escritórios de acompanhamento em tempo real do preço dos produtos agropecuários no mercado internacional através das principais bolsas. Tudo em um processo contínuo, onde a instalação dos fixos passa a ter uma estratégia fundamental nos ganhos comerciais.

Este artigo, objetiva analisar as transformações ocorridas na microrregião sudoeste de Goiás nos últimos nãos, caracterizando os principais municípios do agronegócio Goiano. Esta pesquisa se caracteriza como uma pesquisa bibliográfica e documental com coleta de dados secundários.

\section{Metodologia}

Quanto aos procedimentos da pesquisa, este estudo se classifica como bibliográfica e documental. A pesquisa bibliográfica foi confeccionada a partir de pesquisas em plataformas nacionais e internacionais, fazendo o uso de literatura, revistas especializadas, dissertações, teses, relatórios de pesquisa, artigos e periódicos impressos e eletrônicos. O referencial 
teórico - que compõe a parte bibliográfica da presente pesquisa - trouxe em seu bojo questões ligadas principalmente a modernização agrícola e tecnificação do campo em municípios de Goiás, onde a base econômica é pautada na produção agropecuária.

Já a pesquisa documental pautou-se nos relatórios institucionais, documentos e sítios oficiais de instituições governamentais. Assim, nesta pesquisa, para uma compreensão do processo ocupação e organização da região Sudoeste de Goiás, a partir de uma abordagem quali-quantitativa, foi fundamental a pesquisa documental, que se deu a partir da coleta de dados secundários realizada em relatórios e/ou documentos de cobertura nacional, regional e municipal, produzidos e obtidos nos seguintes órgãos: Ministério do Desenvolvimento Agrário (MDA); Instituto Nacional de Colonização e Reforma Agrária (INCRA); Companhia Nacional de Abastecimento (CONAB); Secretaria de Estado de Gestão e Planejamento do Estado de Goiás (SEGPLAN-GO); Ministério da Agricultura, Pecuária e Abastecimento (MAPA); Secretaria de Agricultura Familiar do Ministério de Desenvolvimento Agrário (SAF/MDA); Instituto Brasileiro de Geografia e Estatística (IBGE); Instituto Mauro Borges (IMB); dentre outros. Foram consideradas, sobretudo, as unidades espaciais (escala geográfica) local e regional, sendo obtidos em periódicos - principalmente nas áreas de Geografia e Ciências Agrárias - alocados em sítios virtuais.

\section{O Sudoeste de Goiás: caracterização}

A região sudoeste do estado de Goiás é uma das 18 microrregiões de planejamento ali existentes, pertencente à região de planejamento do sudoeste goiano e à mesorregião sul goiano. Os 18 municípios que fazem parte da referida microrregião compreendem uma área de 56.083,80 km². Em 2020 tinha uma população estimada de 543.447habitantes (IBGE, 2021), representando 7,67\% da população total do estado de Goiás e uma densidade demográfica de $9,94 \mathrm{hab} / \mathrm{km}^{2}$, considerada baixa se comparada à densidade demográfica de Goiás, que em 2017 era de 19,93 hab/km².

É formada pelos seguintes municípios: Doverlândia, Santa Rita do Araguaia, Portelândia, Mineiros, Caiapônia, Palestina de Goiás, Montividíu, Santo Antonio da Barra, Perolândia, Jataí, Rio Verde, Serranópolis, Chapadão do Céu, Aporé, Aparecida do Rio Doce, Castelândia, Maurilândia e Santa Helena de Goiás (Figura 1).

Figura 1 - Microrregião sudoeste do estado de Goiás.

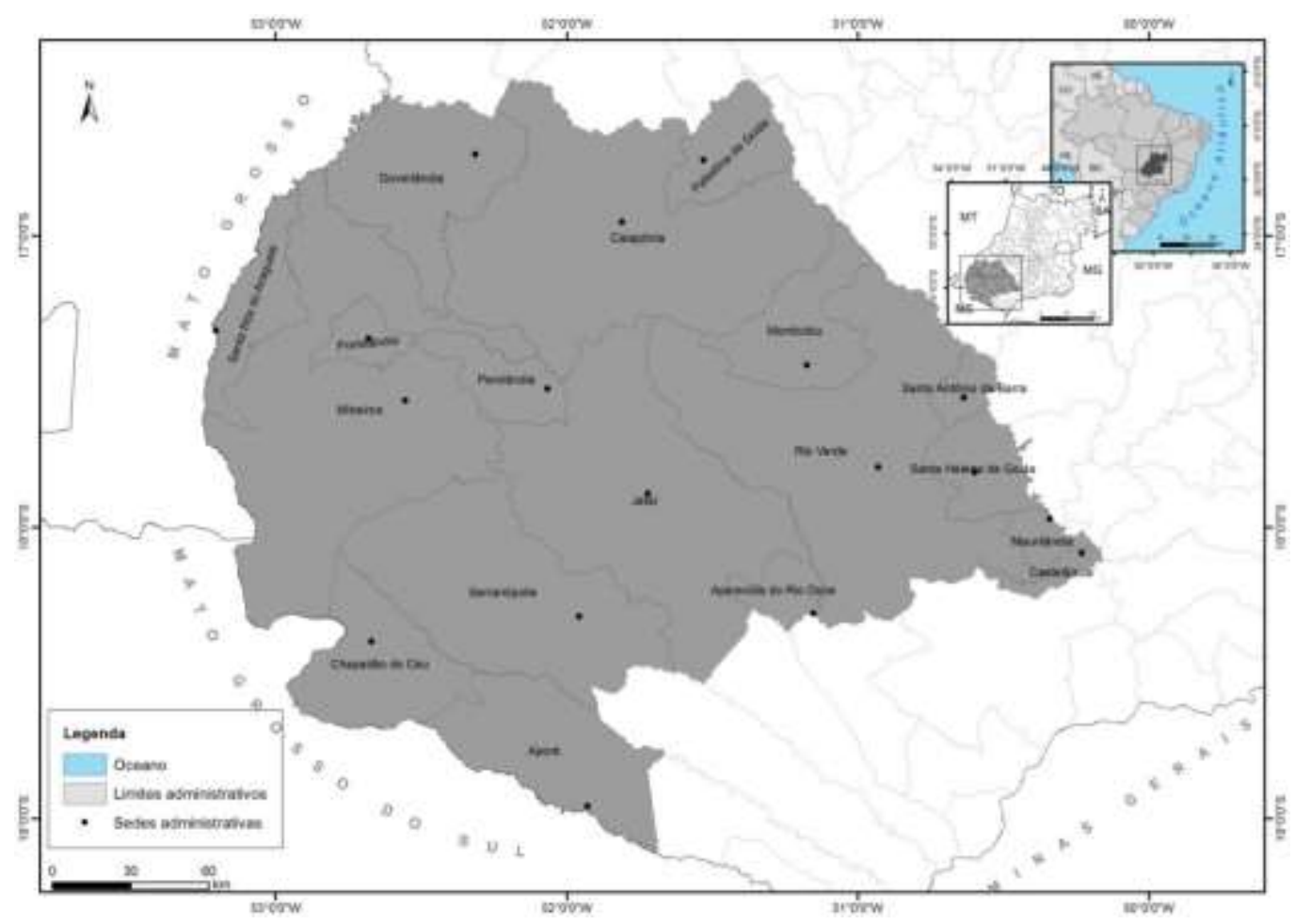

Fonte: Sistema Estadual de Geoinformação (SIEG), (2014). Org. Queiroz Júnior, V. S. (2014). 
De acordo com estimativas do IBGE (2019), Rio Verde é o município mais populoso daquela região (229.651 hab), acompanhado por Jataí (99.674 hab), que se destacam entre os municípios mais promissores do estado de Goiás. A região sudoeste de Goiás apresenta os melhores índices de desenvolvimento econômico e social da UF.

Em 2010, a região apresenta média do Índice de Desenvolvimento Humano Municipal (IDH-M) de 0,59 em educação, 0,82 em longevidade e 0,71 em renda (IMB, 2019). Porém, tal índice tem relação com os aspectos de longevidade, escolaridade e renda - aspectos analisados por média, que podem mascarar a desigualdade e distribuição, sendo possível encobrir as contradições e desigualdades existentes na produção do território, não refletindo a total realidade da região. Exemplo disso é que, considerando apenas a escolaridade - uma das variáveis medidas pelo IDH municipal -, a melhoria no referido índice reflete a chegada de novos profissionais atraídos pelas grandes agroindústrias, que, ao atrair profissionais mais qualificados para os municípios, contribui para o aumento desse indicador, não representando, de fato, investimentos e melhorias na educação e acesso à escolarização da população local. Isso fica comprovado, por exemplo, com a pesquisa de campo com os agricultores sujeitos desta pesquisa.

De acordo com o IMB (2019), em 2018, a região apresentou um rendimento médio de $\mathrm{R} \$ 2.156,97$ e em 2016 e um produto interno bruto per capita de 47.164,32 (média da região). O mapa de uso das terras da microrregião do sudoeste do estado de Goiás apresentado na Figura 2, a seguir, evidencia a existência de uma predominância de áreas destinadas ao cultivo de pastagens e culturas temporárias.

Figura 2 - Uso e cobertura da terra na microrregião do sudoeste do estado de Goiás.

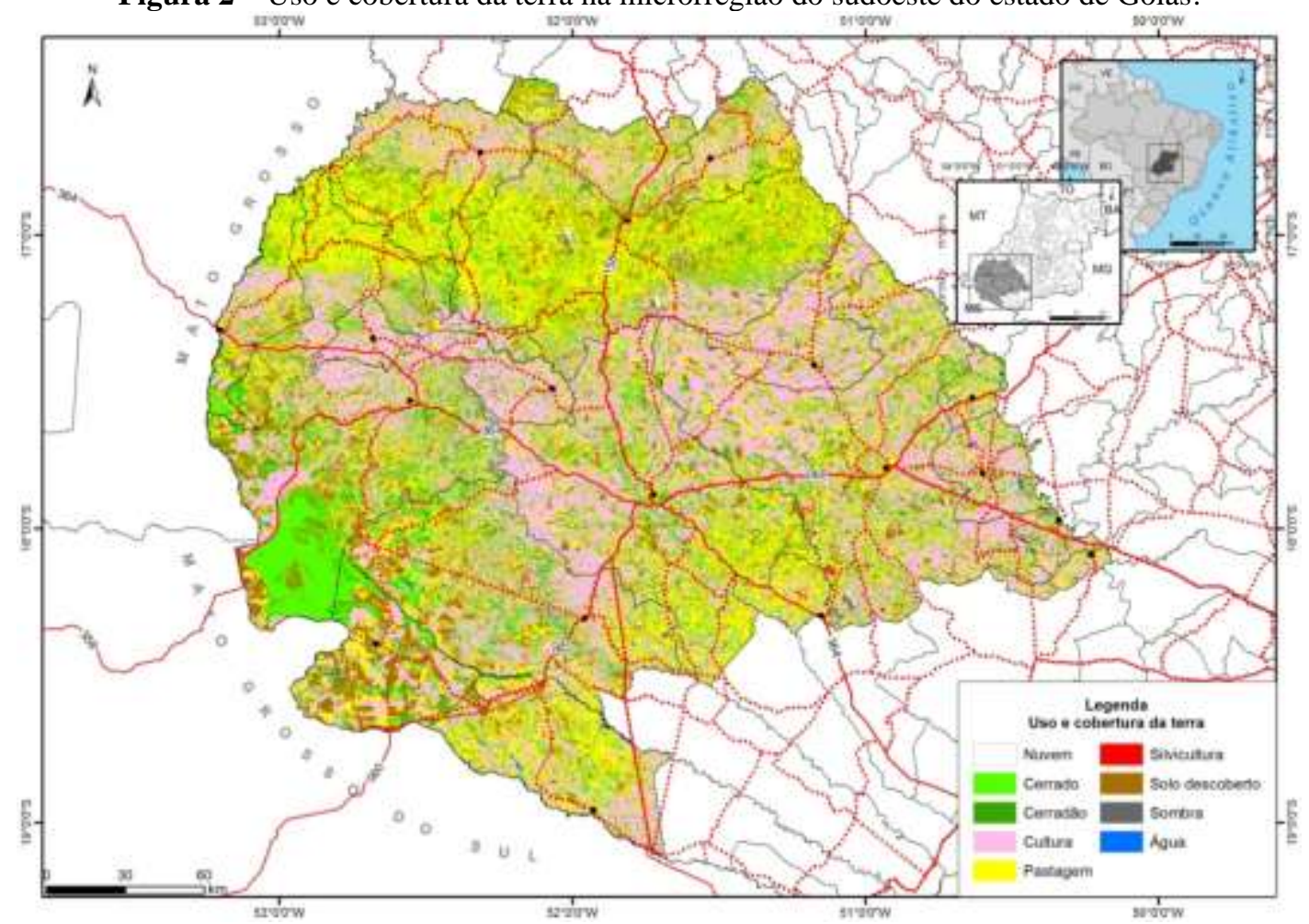

Fonte: Sistema Estadual de Geoinformação (SIEG), (2014). Imagem Landsat8 6R5G4B, sensor OLI de (2013). Organização: Queiroz Júnior, V. S. (2014).

A região apresenta um clima tropical com temperaturas elevadas e altos índices pluviométricos no verão, e poucas chuvas e temperaturas baixas no inverno, principalmente nos meses de junho e julho (Silva, 2010). Para Scopel et al. (2005, p. 41), "o clima é um fator determinante nas atividades desenvolvidas na região, sendo os fatores térmicos e hídricos decisivos para a viabilidade e distribuição geográfica da agropecuária na área”. 
Localizada na borda setentrional da Bacia do Paraná (Scopel et al., 2005), a região tem um relevo basicamente composto por chapadões, com a ocorrência de serras com encostas escarpadas (Carmo; Guimarães; Azevedo, 2002). Predominam os Latossolos Vermelhos e, apesar da baixa fertilidade, o relevo, as baixas declividades e a grande espessura desse solo favorecem a agricultura mecanizada (IMB, 2011), fazendo com que a região aqui analisada ocupe uma posição de destaque no cenário estadual e nacional, considerada um verdadeiro celeiro da produção agropecuária (IMB, 2003).

A vegetação natural da microrregião do sudoeste do estado de Goiás é o Cerrado, porém grande parte dessa foi substituída por pastagens e, nas últimas décadas, com a chegada e o desenvolvimento de culturas de grande escala, houve uma retirada em massa da vegetação original. A forma de extensas áreas no sudoeste daquela UF para a agricultura comercial tem causado o empobrecimento do bioma Cerrado - um problema que se agrava em razão do caráter predatório do modelo agropecuário inserido no bioma, tornando-se, assim, o problema central da ocupação territorial (Silva, 2010).

\section{A Ocupação e a Tecnificação do Campo no Sudoeste de Goiás}

O sudoeste de Goiás tem uma ocupação bastante antiga, concentrando a maior parte da produção agropecuária do estado, e se destacando como um polo de atração de projetos agroindustriais que demandam grande quantidade de matériaprima (grãos, aves e suínos, por exemplo). Tal aspecto tem levado a um uso mais intenso das terras dos municípios que compõem região (Carmo; Guimarães; Azevedo, 2002).

Gonçales (2003) afirma que, na formação econômica, a região sudoeste do estado de Goiás apresentou diferenciadas etapas: a primeira vai da ocupação até o fim do século XX, caracterizada pela exploração da pecuária extensiva. Em seguida, o destaque deu-se pela produção de arroz, milho e feijão. E, nas últimas décadas, caracterizou-se pela incorporação de tecnologias avançada no campo.

A ocupação da região sudoeste do estado de Goiás deu-se por volta do século XIX, com a economia pautada na pecuária, pois a região não fazia parte do ciclo mineratório e, aos poucos, consolidou-se como o novo eixo central da produção goiana. Eram predominantes a produção pecuária e produção de arroz em Rio Verde, bem como em quase todo o estado, até os anos 1960 (Pedroso; Pedroso da Silva, 2005).

Mesmo com uma ocupação, sobretudo, de baixa densidade demográfica, a região sudoeste do estado de Goiás era considerada uma região de terras improdutivas, o que, conforme Guimarães (2010), tornava as terras daquela UF sem valor comercial. Como bem notou Borges (2012), o preço baixo da terra e os incentivos/investimentos favoreceram a migração de produtores das regiões Sul e Sudeste do Brasil para a região sudoeste do estado de Goiás, que compraram extensas áreas com a venda das terras valorizadas nas suas regiões de origem.

Após experimentar uma considerável expansão entre o final da década de 1950 e meados da década de 1960, a região passou por algumas oscilações em termos de crescimento da produção agropecuária. A dependência dos preços vinculados à política de fomento à industrialização do Governo Federal fez com que a região experimentasse momentos de expansão e retração. As respostas em relação à referida oscilação se deram de forma diferente pelo conjunto de municípios da microrregião analisada, evidenciando alguns mais vulneráveis a essas dificuldades, enquanto outros avançam com maior facilidade. Assim, "as transformações no setor agropecuário nessa região, em particular, são desencadeadas no bojo das mudanças na economia nacional, que atingiram de forma diferenciada a agricultura e a pecuária” (Leal, 2006, p. 54).

Na região sudoeste do estado de Goiás, a produção em escala chega representada pela soja, via município de Rio Verde na década de 1960. Seu pioneirismo é atribuído, sobretudo, a alguns produtores a partir da contribuição de técnicos da extinta Associação de Crédito e da Assistência Rural de Goiás (ACAR-GO) (Barreto, 2007), que em 1999 é transformada em Agência Rural. Essa produção agrícola é pioneira na transformação e modernização ali ocorridas. 
Segundo Leal (2006), a proximidade dos centros comerciais fez com que o município de Rio Verde se caracterizasse como o principal polo econômico da região sudoeste do estado de Goiás. Na década de 1970, a inserção da soja provocou transformações na produção agrícola regional, articulada ao processo de agrodindustrialização. A lavoura dessa leguminosa deu-se com o uso intensivo de máquinas agrícolas e implementos tecnológicos, que não estão ao alcance da pequena produção e dos agricultores tradicionais.

Com o desenvolvimento da pesquisa, os solos da região, antes considerados improdutivos, tornaram-se terras muito férteis, com a Revolução Verde e a chegada de agricultores capacitados com tecnologias (Guimarães, 2010). Em tal período, o a região integrou-se à economia nacional, transformando-se em área de grande interesse agrícola comercial, ocorrendo um forte fluxo migratório para o sudoeste de Goiás.

As consequências da Revolução Verde e da modernização agrícola atingiram as estruturas produtivas que davam sustentação aos pequenos agricultores, fazendo com que esses fossem empurrados para espaços marginais, que não são visados pela estrutura produtiva monocultora. Possivelmente, tem-se aqui a origem da ocupação das faixas de domínios, como resultado das transformações impostas pelo novo modelo de produção agrícola. Nesse sentido, Pires (2008) afirma que houve uma ruptura entre a exploração agropecuária de subsistência e a modernização agrícola.

Foi em um contexto de busca e disputa pela melhor localização geográfica possível e de solo que se deu a territorialização da monocultura da soja, do milho e do sorgo na região sudoeste do estado de Goiás, acarretando, assim, um rearranjo territorial do espaço agrário nessa porção do território goiano. A territorialização da produção de grãos em larga escala na referida região provocou uma monopolização desta porção do espaço geográfico, por meio do controle da terra, dos recursos naturais, da força de trabalho e do acesso a políticas públicas. Os pequenos proprietários foram aos poucos expropriados e excluídos das políticas públicas. Segundo Pires (2008, p. 54), quando os proprietários dos minifúndios não tinham a titulação da terra, esses eram expulsos até mesmo com uso de violência.

Fockink (2007) destaca que a dimensão da propriedade era requisito básico para o acesso às políticas para o campo brasileiro. Assim, o pequeno produtor agrícola foi obrigado a vender ou arrendar suas terras, migrando para a cidade, empregando-se nos serviços urbanos ou mantendo-se em subempregos temporários nas grandes propriedades rurais, ou seja, trabalho sazonal nos períodos de plantio e colheita.

O processo de modernização agropecuária provocou grandes transformações nas relações de produção no espaço utilizado dos municípios de Rio Verde e Jataí, que apresentou altas taxas de crescimento populacional e de produção desde a década de 1970. Partícipes de tal processo foram os muitos interesses globais interligados com empresas multinacionais e o Estado, que atuou na estruturação e modernização dos fixos, além de contribuir para a territorialização do capital por meio da agricultura moderna.

Tais transformações somente se deram em função dos subsídios e incentivos fiscais fornecidos pelo Estado, que visavam à abertura de novas áreas produtivas, infraestrutura adequada, processamento, comercialização e transporte dos produtos agrícolas produzidos nos municípios. Transformações impostas ao espaço podem ser observadas na intensificação da reestruturação da produção agropecuária na região sudoeste de Goiás, bem como na redefinição das relações de produção e de trabalho.

Na década de 1980, essa região recebeu o maior incremento populacional do estado, superando o crescimento de $10 \%$ de Goiás. Quando comparadas às décadas de 1970 e 1980, tem-se um crescimento da população urbana do Município de Jataí de 60,78\%, e do município de Rio Verde de 105,90\%, e um decréscimo na população rural de 28,60\% em Jataí, e 33,66\% em Rio Verde. Ao considerar os índices populacionais urbanos entre as décadas de 1970 e 2000, é possível observar um crescimento populacional de 157,88\% em Jataí, e 292,26\% em Rio Verde, enquanto que o índice populacional rural diminuiu, apresentando queda de 54,82\% em Jataí, e 63,45\% em Rio Verde (Leal, 2006). 
Destarte, existem profundas diferenças nos municípios que compõem a região aqui analisada, pois, pela seletividade da aplicação de capitais, alguns desfrutam de excelente infraestrutura pública e privada, enquanto outros estão sempre na espera, mostrando uma diferenciação interna constantemente recriada (Silveira; Barreira, 2012). Desse modo, a modernização do território ocorrida nos municípios em questão não é suficiente para fornecer infraestrutura aos trabalhadores em termos de moradia, segurança, saneamento básico etc., ocorrendo a modernização apenas no âmbito das bases produtivas.

O Censo Demográfico de 2010 mostra que as localidades de Rio Verde e Jataí estão entre os 20 municípios goianos mais populosos. Na classificação dos municípios goianos empregada por Chaveiro (2010), na região sudoeste do estado de Goiás têm-se os municípios deprimidos e os municípios indomáveis, ou seja, enquanto os deprimidos não dão oportunidades para que os indivíduos desenvolvam a produção de sua existência, favorecendo a migração, "há lugares indomáveis em que as suas condições sociais e econômicas os transformam em centros de afluxos da população, levando-os a uma taxa de crescimento vertiginoso, implicando, também, na sua instabilidade" (Chaveiro, 2010, p. 1).

E ainda, enquanto as cidades maiores se tornam espaços indomáveis, atraindo mais população e aumentando as desigualdades, passam a sofrer os problemas advindos desse crescimento, que vão desde problemas ambientais a estruturais (desemprego, falta de moradia, transporte etc.) e existenciais (medo e violência urbana, por exemplo). A seleção "dessas cidades pelas políticas públicas e pela intervenção do Estado para serem lugares do desenvolvimento econômico ocorre mediante a sua posição diante das regiões hegemônicas do país", especialmente em relação ao sudeste (Chaveiro, 2010, p. 29). Conforme Tabela 1, verificam-se municípios com crescimento populacional geométrico significativo, enquanto outros apresentam até mesmo crescimento negativo.

Tabela 1 - População, densidade demográfica e taxa de crescimento.

\begin{tabular}{l|c|c|c|}
\hline Município & Densidade Demográfica & População Total & $\begin{array}{c}\text { Taxa de Crescimento } \\
\text { Populacional }\end{array}$ \\
\hline Aparecida do Rio Doce & 4,18 & 2.517 & 0,52 \\
\hline Aporé & 1,43 & 4.143 & 1,23 \\
\hline Caiapônia & 2,14 & 18.505 & $-0,11$ \\
\hline Castelândia & 12,12 & 3.610 & 3,83 \\
\hline Chapadão do Céu & 4,17 & 9.110 & $-0,26$ \\
\hline Doverlândia & 2,41 & 7.750 & 1,57 \\
\hline Jataí & 13,68 & 98.128 & 2,16 \\
\hline Maurilândia & 34,33 & 13.379 & 2,46 \\
\hline Mineiros & 6,94 & 62.750 & 2,5 \\
\hline Montividiu & 6,72 & 12.566 & 0,6 \\
\hline Palestina de Goiás & 2,66 & 3.514 & 0,87 \\
\hline Perolândia & 3,04 & 3.135 & 0,75 \\
\hline Portelândia & 7,27 & 4.044 & 3 \\
\hline Rio Verde & 25,88 & 217.048 & 0,87 \\
\hline Santa Helena de Goiás & 33,94 & 38.743 & 2,48 \\
\hline Santa Rita do Araguaia & 6,06 & 8.218 & 1,12 \\
\hline Santo Antônio da Barra & 10,58 & 4.780 & 1,54 \\
\hline Serranópolis & 1,51 & 8.323 & Média: 1,47 \\
\hline
\end{tabular}

Fonte: IBGE $(2010 ; 2015)$.

Assim, as pequenas cidades perdem população, transformando-se em forças de retração, tornando-se espaços deprimidos ao perderem a vitalidade socioeconômica por meio do balanço migratório negativo (Chaveiro, 2010). Para Elias (2005) o modelo de crescimento agropecuário em questão privilegiou áreas, produtos e segmentos sociais, provocando profundos impactos sociais, territoriais e ambientais que, por sua vez, culminaram na intensificação da concentração fundiária, na oligopolização do setor, em mudanças das relações sociais de produção, na fragmentação do espaço agrícola e na urbanização do campo. 
Dessa forma, os programas governamentais provocaram profundas transformações que levaram ao aumento da produção, da produtividade e de área cultivada na região sudoeste do estado de Goiás. Tais transformações somente se deram em função dos subsídios e incentivos fiscais fornecidos pelos governos federal e estadual, que visavam à abertura de novas áreas produtivas, infraestrutura adequada, processamento, comercialização e transporte dos produtos agrícolas produzidos nos municípios. Todavia, assim como nas outras regiões do estado, nessa microrregião, os pequenos produtores, com suas pequenas extensões de terras, não desfrutaram das políticas públicas.

\section{O Estado e a Modernização Agropecuária no Sudoeste do Estado de Goiás}

O fomento do Estado para a grande produção possibilitou a substituição de forma gradativa de métodos tradicionais de produção agropecuária por métodos de produção em grande escala, com a intensificação de insumos industriais químicos e biológicos e o intenso uso de maquinários e novas formas de trabalho. Ao direcionar as políticas públicas, o estado direcionou também a ocupação das áreas produtivas de Goiás. Tal direcionamento certifica a afirmação de Vinhas (1980, p. 67): “[...] a prática agrícola pode ser orientada na direção em que o Estado projetar”.

A chegada dos sulistas - conhecidos na região por gaúcho, independente do seu estado originário no Sul - na referida região ocorreu de modo contínuo nas décadas de 1970 a 1980 - período de intensa ocupação de novas áreas de produção agrícola e momento de implementação das principais políticas de financiamentos agropecuários na microrregião. A territorialização dessa população nos domínios de chapadões planos, de fato, foi fundamental para a consolidação da região sudoeste da UF em questão, enquanto locus crescente da produção agrícola moderna exportadora.

As políticas estatais de modernização do território impulsionaram a modernização agrícola no sudoeste do estado, condicionando o território a uma nova dinâmica econômica de configuração socioespacial, pautado em uma mecanização das atividades agrícolas e na concentração fundiária, o que corrobora com Matos e Pessoa (2010), ao afirmarem que a consolidação da modernização agrícola somente se deu porque foi articulada por e com políticas públicas direcionadas para o desenvolvimento agropecuário do País, com base na implantação de infraestrutura, de programas e do desenvolvimento de pesquisas.

A presença do Estado por meio de mecanismos de créditos, incentivos fiscais e outras políticas promoveu a modernização agrícola enquanto processo concentrador e excludente na região sudoeste do estado de Goiás. Sinhorini e Saquet (2005, p. 7) esclarecem que os investimentos estatais na mecanização e linhas de créditos a juros negativos atenderam e ainda atendem apenas uma pequena parte dos agricultores, enquanto excluem a maioria desses.

Em meados da década de 1960, foi instituído o Sistema Nacional de Crédito Rural (SNCR) - uma linha de crédito direcionada à produção agropecuária, que contribuiu para o desenvolvimento agropecuário goiano, detendo entre os seus objetivos o estímulo aos investimentos no campo com ações de armazenamento, beneficiamento, industrialização e comercialização dos produtos agropecuários (Guerra, 2012).

Segundo Goulart (2012), na região sudoeste do estado de Goiás a modernização agropecuária foi beneficiada pelas políticas públicas de desenvolvimento para a região Centro-Oeste no âmbito dos programas federais I e II PND. A partir da criação da Superintendência de Desenvolvimento do Centro-Oeste (SUDECO), em 1967, teve início a formulação de alguns programas, tais como: o Programa de Desenvolvimento da Região Sudoeste (PRODOESTE), o Plano de Desenvolvimento Econômico-Social do Centro-Oeste (PLADESCO) e o Programa para o Desenvolvimento do Cerrado (POLOCENTRO). E, ainda, vale destacar a criação do Fundo Constitucional do Centro-Oeste (FCO), em 1989.

A participação do Estado por meio da viabilização dos incentivos fiscais na modernização brasileira deu-se na região sudoeste de Goiás, principalmente por meio dos programas POLOCENTRO e Programa Nipo-Brasileiro para o Desenvolvimento do Cerrado (PRODECER). Esse último instituído em 1975 buscou incorporar aproximadamente 3,7 milhões 
de hectares de cerrados na produção agropecuária em quatro anos. Goiás o estado que mais se beneficiou do programa, sobretudo sua microrregião sudoeste. Cerca de dois milhões de hectares foram incorporados, dos quais $42 \%$ era território do sudoeste daquela UF (Guimarães, 2010).

A região sudoeste do estado de Goiás foi uma das 12 áreas de Cerrado beneficiadas pelo POLOCENTRO, que teve como principal objetivo o desenvolvimento e a modernização das atividades agropecuárias na região Centro-Oeste e no oeste do estado de Minas Gerais. Aquele Programa foi criado dentro do II Programa Nacional de Desenvolvimento (II PND), uma das causas da povoação e inserção da região Centro-Oeste no mercado nacional. Fazia parte do Programa toda infraestrutura adequada visando ao desenvolvimento do capital, ou seja, transformar a área do Cerrado, substituindo as técnicas até então existentes, por novas técnicas e novos mercados econômicos. Porém, o Programa acentuou a concentração fundiária, beneficiando a produção em larga escala, por meio de créditos e de assistência técnica, enquanto as pequenas propriedades praticamente ficaram sem recursos e benefícios.

De acordo com Borges (2006), os investimentos em infraestrutura, a especulação e as políticas de créditos excludentes, elementos da modernização agrícola, provocam a venda das terras dos pequenos produtores, fazendo com que esses sejam seduzidos pelas vantagens da vida na cidade, crescendo, assim, o número de médios e grandes produtores a partir da compra de terras dos pequenos e contribuindo para a concentração fundiária.

Dados do IBGE apresentados por Borges (2006) mostram que, após anúncio e efetivação dos investimentos do POLOCENTRO, no sudoeste de Goiás ocorreu uma forte concentração de terras. O preço da terra subiu em cerca de $170 \% \mathrm{em}$ alguns locais em 1970. Já em 1980, um percentual de 68,6\% da área agrícola da microrregião estava concentrado em estabelecimentos rurais com área superior a $1.000 \mathrm{hA} \mathrm{e} \mathrm{2,61 \%} \mathrm{ocupada} \mathrm{por} \mathrm{pequenos} \mathrm{estabelecimentos.}$

O padrão de financiamento público da agricultura de créditos negativos esgotou-se no início da década de 1980 em razão da intensificação da crise fiscal do Estado brasileiro. A partir do ano de 1984, as taxas de juros que incidiram sobre o crédito rural oficial se tornaram positivas, uma vez que, em 1980 e início da década de 1990, identificou-se uma instabilidade macroeconômica no País (Hespanhol, 2008).

O crédito subsidiado foi utilizado como instrumento de exclusão dos pequenos agricultores. Era facilitado aos grupos com mais recursos e capitalizados, e, portanto, a esses era privilegiado, ao mesmo tempo em que excluía, pela dificuldade de acesso, pequenos agricultores e descapitalizados, provocando uma divisão de trabalho crescente, onde as grandes propriedades, de terras melhores, acessavam "os créditos, subsídios, tecnologia, pesquisa e assistência técnica, a fim de produzir para o mercado externo ou para a agroindústria" (Martine, 1991, p. 10).

As políticas de crédito fundiário atraíram um grande número de produtores para a região Centro-Oeste, consolidando, assim, as culturas de soja e milho, que mais tarde se tornaram a base para o complexo industrial de grãos/carnes (Carmo; Guimarães; Azevedo, 2002). Em Rio Verde e Jataí, as políticas agrícolas também foram direcionadas ao abastecimento do mercado externo.

Criado pela Lei n. 9.489 de 1984, o Fundo de Fomento a Industrialização do Estado de Goiás (FOMENTAR), centrado na isenção do Imposto sobre Circulação de Mercadorias e Prestação de Serviços (ICMS), atraiu, apenas na primeira metade do ano de 1997, investimentos da ordem de $\mathrm{R} \$ 952,5$ milhões, com a aprovação de 357 projetos e distribuição de créditos fiscais no valor de R \$ 9,04 bilhões, beneficiando 212 empresas. Tal programa financiava $70 \%$ do ICMS, com juros de 2,4\% ao ano, sem correção monetária e prazos de até 25 anos (Pedroso; Pedroso da Silva, 2004). Em 2000, foi substituído pelo Programa de Desenvolvimento Industrial de Goiás (PRODUZIR), pela Lei n. 13.591.

No período 1991-1999 várias empresas instaladas nos municípios de Jataí e Rio Verde foram beneficiadas pelo FOMENTAR. A maioria dessas empresas atua diretamente no setor agropecuário ou presta serviços para agroindústrias. O Programa PRODUZIR, entre os anos de 2001 e 2012, aprovou 1.399 projetos. Desses, 650 foram contratados, contemplando 
81 municípios em 17 das 18 microrregiões do estado de Goiás. Porém, a microrregião do sudoeste goiano recebeu os maiores investimentos, representando 23,29\% do total, sobretudo ao setor sucroalcooleiro (Romanatto, Arriel; Lima, 2012).

A partir daí a estrutura produtiva regional de grãos se constitui um verdadeiro cenário paisagístico de áreas planas e cultivos quase que homogêneos de produção agrícola especializada, em escala e para exportação. Tais espaços se repetem por várias extensões de terras e escondem relações conflituosas e excludentes; e revelam espaços heterogêneos de lutas históricas, sociais, econômicas e conflitos ambientais, com a presença de agentes ativos de produção e reprodução espacial no território. Contudo, além do estado, na microrregião aqui em análise, os agricultores - sulistas detentores de conhecimento das novas técnicas e tecnologias de produção agropecuária - constituíram outro instrumento poderoso de transformação do espaço, que é ocupado gradativamente pela grande produção agropecuária.

\section{As Cidades do Agronegócio Goiano}

Os processos de modernização agropecuária, que provocaram as recentes transformações no território, fazendo-o se integrar aos circuitos globais, fizeram com que as principais cidades do sudoeste de Goiás se transformassem nas cidades do agronegócio. Sobre isso, Elias considera as cidades do agronegócio um novo tipo de tipologia de cidade.

[...] cidades em regiões agrárias que vêm enriquecendo [...] polariza amplo espaço agrário dinâmico, é um centro urbano que organiza esse espaço. [...] a cidade do agronegócio está inserida em Regiões Produtivas Agrícolas na confluência do agrário moderno com espaços urbanos não metropolitanos, e configura um lugar central de uma Região Produtiva Agrícola, parte integrante das redes agroindustriais, reflexo, meio e condição para o funcionamento dessas (2011, p. 162).

Para Elias (2012), essas áreas são compostas por espaços agrícolas modernos, extremamente racionalizados, e por espaços urbanos não metropolitanos. Esses espaços estão em conexão com os centros de poder e consumo em escala mundial e as escalas locais e regionais em permanente articulação com as escalas nacionais e internacionais, fazendo com que a organização do território se dê a partir da imposição do mercado, controlado pelas empresas nacionais e multinacionais.

Elias (2012) entende esses territórios produtivos do agronegócio como novos arranjos territoriais resultados dos profundos impactos sobre a (re)organização do território a partir das transformações ocorridas na agropecuária brasileira. Para a autora, esses territórios produtivos globalizados são compostos

tanto pelos espaços agrícolas como pelos urbanos escolhidos para receber os mais sólidos investimentos privados, formando os focos dinâmicos da economia agrária, ou seja, são áreas de difusão de vários ramos do agronegócio, palco de circuitos superiores do agronegócio globalizado (Elias, 2012, p. 3).

Os municípios de Rio Verde e Jataí foram beneficiados por programas financiados pelos Governos Federal e Estadual, que a incorporação de terras com preços relativamente baixos, com base na intensificação do uso de capital, da correção da acidez dos solos característicos das áreas de Cerrado e da mecanização da produção agrícola, possibilitada pelo fornecimento de créditos e pela implantação de infraestrutura básica.

Logo, tais localidades se tornaram grandes potenciais para a expansão da agricultura devido aos seguintes aspectos: localização, solo, clima e relevo propícios à mecanização, além de consequente introdução do pacote tecnológico da Revolução Verde, em um período de grande expansão desse modal pelos países subdesenvolvidos.

Nesse processo, esses municípios se tornam em grande parte em território do agronegócio, que, segundo Cavalcanti e Fernandes (2008, p. 23), "se fundamenta na integração corporativa dos produtores liderada pelas empresas, que reconfiguram o espaço em função da lógica produtiva". Essas empresas na defesa dos seus interesses se unem junto ao Estado e inserem seus 
interesses no orçamento público, realizando um uso competitivo e integrado do território, implantando infraestruturas e concebendo estratégias de ampliação do controle do mercado.

Com uma área territorial de 8.379,66 km² e uma população estimada de 229.651 habitantes (IBGE, 2019), o município de Rio Verde tem uma produção que alcança todos os setores: da pecuária à agricultura, da indústria ao comércio e aos serviços (IMB, 2009) e se localiza cerca de 220 km da capital do Estado, Goiânia. A localidade em questão é servida de duas importantes rodovias federais: a BR-060, que liga a capital federal ao município goiano de Jataí; e a BR-452, que liga Rio Verde a Itumbiara.

O município de Jataí, conta com uma área territorial de 7.174 km² e população estimada em 99.674 habitantes (IMB, 2019). A área urbana dista $323 \mathrm{~km}$ da capital. Aquela localidade tem seu território cortado por três importantes rodovias federais: BR-364, BR-060 e BR-158. Trata-se da única cidade do País servida por três rodovias.

Mais de $60 \%$ da população da região sudoeste do estado de Goiás estão concentrados nos municípios de Jataí e Rio Verde. Dos 538.611 habitantes da microrregião do sudoeste de Goiás, 329.325 viviam nesses dois municípios (IMB, 2019), com 7,7\% de sua população residindo no espaço rural em 2010 (IBGE, 2011).

Contudo, a partir da instalação do agronegócio, não necessariamente a região e os municípios de desenvolvem. É possível perceber um crescimento desordenado, evidenciando o lado excludente e desigual da urbanização nestas cidades, influenciada pela dinâmica desta área mercadológica. Nesse sentido, para Elias e Pequeno (2007), a chegada de imigrantes oriundos de regiões vizinhas e de outros estados contribui para o crescimento urbano desordenado, ao passo que ocorre um crescimento urbano excludente de onde emanam questões associadas à forma desigual do capital, como, por exemplo, o acesso aos benefícios proporcionados pela urbanização e aos conflitos pelo uso do território.

Para Chaveiro (2010, p. 30), "o grau complexo e os variados problemas que originam da urbanização desafiam, igualmente, a ação dos gestores e dos planejadores" desses municípios. Elias e Pequeno (2007, p. 31) destacam que nas cidades do agronegócio observa-se a reprodução dos problemas urbanos comuns nas cidades maiores, como, por exemplo:

[...] ausência ou insuficiência de infraestrutura social (creches, escolas, postos de saúde) nas áreas habitadas pela população de menor renda; surgimento de áreas de ocupação em situação de risco ambiental; favelização nos espaços destinados a usos institucionais e áreas verdes; disseminação de vazios urbanos promovendo a especulação imobiliária; loteamentos periféricos clandestinos desprovidos de infraestrutura; congestionamento nas áreas centrais por movimentação de carga e descarga, dentre outros.

Assim, essas cidades ainda escondem uma pobreza instalada na periferia ali existente e crescente, cada vez mais ocupadas por trabalhadores - urbanos e rurais - em suas mais diversas formas, oriundos das mais diversas categorias sociais do campo (posseiro, meeiro etc.), que, sem a terra, têm como único caminho para a sobrevivência: o acesso ao emprego urbano e a ocupação das áreas periféricas.

A figura 03, a seguir, ilustra o crescimento da densidade demográfica no período 1996-2017 (com intervalor). Os dois municípios aqui analisados apresentam aumento de suas densidades demográficas. Em 1991, Jataí e Rio Verde apresentavam densidades demográficas de $9,19 \mathrm{ha} / \mathrm{km}^{2}$ e $11,48 \mathrm{ha} / \mathrm{km}^{2}$, respectivamente; ambas abaixo da densidade demográfica registrada pelo estado de Goiás. A partir de 2007, enquanto a densidade demográfica do município de Jataí continua apresentando um pequeno crescimento, as taxas deste índice de Rio Verde apresenta crescimento significativo e supera a densidade demográfica do estado de Goiás. Em 2017, enquanto o estado de Goiás apresentou densidade demográfica de 19,93 ha/km², Rio Verde e Jataí apresentaram taxas de 25,88 ha/ $/ \mathrm{km}^{2}$ e 13,68 ha/ $\mathrm{km}^{2}$ respectivamente. 
Figura 3 - Densidade demográfica de Goiás, Jatai e Rio Verde - período 1996-20170.

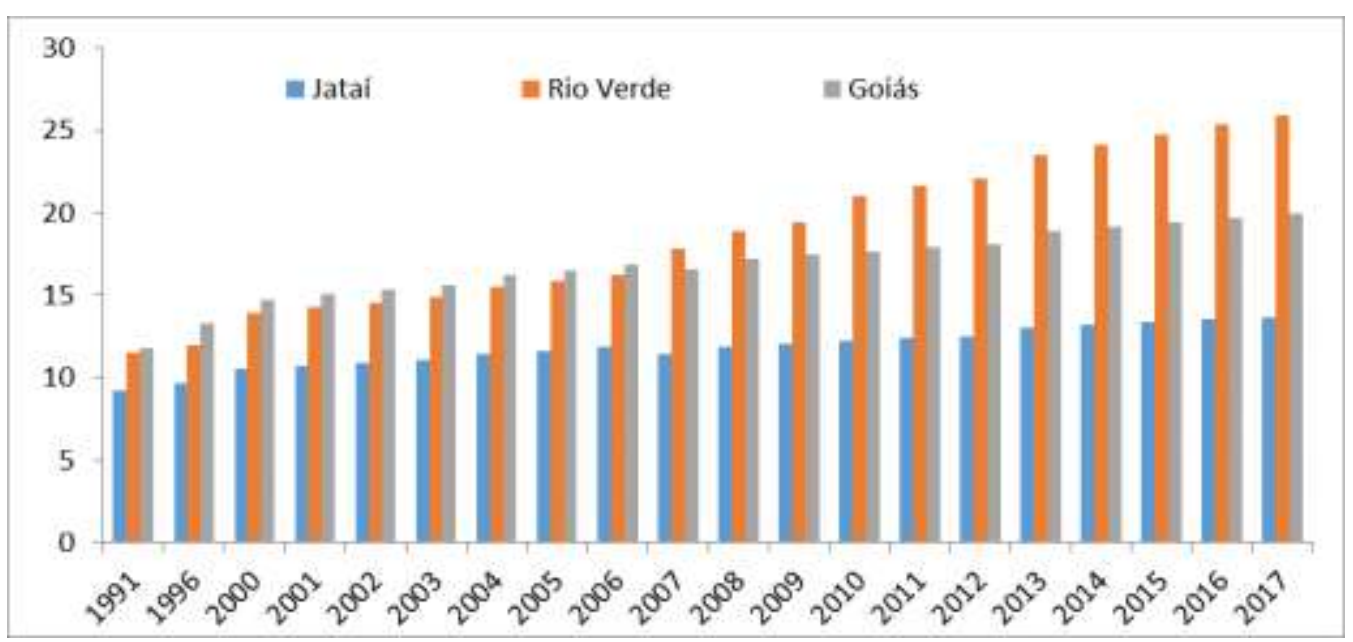

Fonte: IMB, (2019).

Destarte, mesmo a cidade de Rio Verde apresentando, a partir de 2007, uma densidade demográfica superior à média estadual, a média do município de Jataí, no período supramencionado, fica abaixo da média estadual. Tal fato pode ser explicado pelo crescimento populacional de Rio Verde ter sido muito mais expressivo nas últimas décadas do que em Jataí.

Há que se destacar que a atividade agrícola, que dá base aos três principais complexos agroindustriais da região sudoeste de Goiás, apresenta baixa de ocupação no campo - fato que pode ser comprovado quando da análise das percentagens de população rural e urbana no período aqui analisado. Assim, Jataí e Rio Verde, em 2010, tinham apenas 7,9\% e 7,3\% de sua população meio rural respectivamente (Tabela 2).

Tabela 2 - Dados demográficos de Jataí e Rio Verde - GO.

\begin{tabular}{c|c|c|c|c|c|c|c|c}
\hline \multirow{3}{*}{ Município } & & \multicolumn{3}{|c|}{$\mathbf{2 0 0 0}$} & \multicolumn{3}{|c|}{$\mathbf{2 0 1 0}$} & $\mathbf{2 0 1 8}^{*}$ \\
\cline { 2 - 9 } & $\begin{array}{c}\text { Área (em } \\
\left.\mathbf{K m}^{2}\right)\end{array}$ & $\begin{array}{c}\text { População } \\
\text { Total } \\
\text { (hab.) }\end{array}$ & $\begin{array}{c}\text { População } \\
\text { Urbana } \\
\text { (hab.) }\end{array}$ & $\begin{array}{c}\text { População } \\
\text { Rural } \\
\text { (hab.) }\end{array}$ & $\begin{array}{c}\text { População } \\
\text { Total } \\
\text { (hab.) }\end{array}$ & $\begin{array}{c}\text { População } \\
\text { Urbana } \\
\text { (hab.) }\end{array}$ & $\begin{array}{c}\text { População } \\
\text { Rural } \\
\text { (hab.) }\end{array}$ & $\begin{array}{c}\text { População } \\
\text { Total } \\
\text { (hab.) }\end{array}$ \\
\hline Jataí & 7.174 .23 & 75.417 & 68.785 & 6.632 & 88.006 & 81.010 & 6.996 & 99.674 \\
Rio Verde & 8.379 .66 & 116.559 & 106.109 & 10.450 & 176.424 & 163.540 & 12.884 & 229.651 \\
\hline Total & 15.553 .89 & 191.976 & 174.894 & 17.082 & 264.430 & 244.550 & 19.884 & 329.325 \\
\hline
\end{tabular}

Fonte: IBGE. Censo Demográfico (2000); IBGE. Censo Demográfico (2010). *estimativa

Rio Verde e Jataí contam com um contínuo crescimento econômico, sustentado principalmente pelo desenvolvimento de sua agricultura e pela agregação de valor aos produtos agropecuários (IMB, 2015). A economia desses municípios fundamenta-se principalmente na agricultura, pecuária e agroindústria. Na agricultura, destaca-se a produção de milho, soja, sorgo e cana-de-açúcar. Na pecuária, tem-se a criação de bovinos, suínos, aves e a produção de leite.

A territorialização do agronegócio nas áreas do sudoeste de Goiás em muito é explicada pela constituição dos Complexos Agroindustriais. A melhoria nos índices econômicos se deu, sobretudo, a partir da criação de parques industriais, da instalação da empresa BRF Brasil - uma das maiores companhias de alimentos do mundo, com mais de 30 marcas em seu portfólio, entre elas, Sadia, Perdigão, Qualy, Paty, Dánica, Bocatti e Confidence - e da chegada de várias outras empresas e grandes empresas de capital nacional e internacional ligada aos complexos de grãos, carne e cana-de-açúcar. 


\section{Reconfiguração da Microrregião do Sudoeste de Goiás}

A modernização das atividades agropecuárias provocou o desenvolvimento de um conjunto de novas relações campocidade, produzidas pela integração da produção agropecuária ao circuito da economia urbana (Elias; Pequeno, 2007). Os espaços rurais e urbanos passam a conviver com elementos novos e antigos, representando a face da desigualdade existente. Sobre a questão, Antonello (2011, p. 63) afirma que "a territorialização desigual do capital no espaço rural forja o novo e recria o velho, presentes nas novas funções que o espaço rural assume”. Um bom exemplo são os fluxos de veículos nas cidades, onde se encontram os carros antigos, velhos, de baixo custo, disputando espaços nas avenidas com os últimos modelos de caminhonetas, símbolos de status, adquiridos pela elite agrária daquelas localidades.

Os espaços agrários, sobretudo, nas proximidades dessas cidades, são um misto de áreas planas com as produções homogêneas, refletidas nas paisagens, juntamente com a grande quantidade de agroindústrias, silos e armazéns que estocam a volumosa produção em escala. Nesse sentido, Elias e Pequeno (2007, p. 27) observam que ali "processa-se [...] um crescimento de áreas urbanizadas também no campo [...] nas áreas que se modernizam, uma vez que [...] a gestão do agronegócio globalizado necessita da sociabilidade e dos espaços urbanos". Esses autores entendem que "o agronegócio globalizado tem o poder de impor especializações territoriais cada vez mais profundas".

Entre as principais culturas temporárias na região sudoeste do estado de Goiás, destacam-se a soja, o milho e a canade-açúcar - em processo de expansão acelerada. Em 2017, tais culturas ocupavam as maiores áreas da região nos Municípios de Rio Verde (588.000 ha) e Jataí (527.000 há). Na pecuária, tem-se a criação de bovinos, aves e a produção de leite, entre outros produtos (IMB, 2018).

A instalação de agroindústrias no sudoeste de Goiás fez aumentar a demanda por matéria-prima nos últimos anos, fazendo com que os agricultores expandissem as áreas de produção de grãos nessa microrregião, intensificando, por exemplo, a segunda safra do milho (safrinha), implantada logo após a colheita da soja. Na safrinha, desde 2011, produz mais do que a produção do milho de verão (Silva; Francischini, 2013).

Em 2014, dos três municípios que apresentaram o maior valor de produção agrícola em Goiás, dois se localizam em sua microrregião sudoeste, a saber: Jataí - com $\mathrm{R}$ \$ 1,4 bilhões - e Rio Verde - com $\mathrm{R} \$ 1,3$ bilhões de valor de produção agrícola, ficando atrás somente de Cristalina, que alcançou $\mathrm{R}$ 1,6 bilhões de valor de produção agrícola. Jataí e Rio Verde em 2017 foram os municípios goianos que mais produziram soja e milho, ficando Rio Verde com a primeira posição com 2.654.100 toneladas e Jataí, em segundo lugar com 2.566.200 toneladas produzidas. Tal aspecto faz com que esses municípios se destaquem como os dois principais produtores de grãos de Goiás.

Em várias áreas rurais, a urbanização ocorreu diretamente à consecução do agronegócio globalizado. A urbanização é acelerada pela reestruturação das atividades agrícolas, que também acelera o processo de produção de espaços urbanos não metropolitanos, onde as conexões fundamentais devem-se às constantes inter-relações entre o campo e a cidade. O desenvolvimento das cidades se dá atrelado às atividades agrícolas, ao mesmo tempo que delas depende em diversos graus. Sobre a questão, Elias $(2012$, p. 8) considera que "o agronegócio globalizado exerce papel fundamental para a expansão da urbanização e para a reestruturação urbana e regional".

Tais processos provoca um reordenamento no modo de produzir e organizar a produção agropecuária e nas relações sociais no campo, bem como na cidade. Para Elias e Pequeno (2007, p. 26), as cidades do agronegócio "tornam-se responsáveis pelo suprimento de suas principais demandas [...] aumentando a economia urbana".

Os espaços urbanos próximos ao espaço agrícola vão se adaptando para atender às demandas da produção agropecuária e agroindustrial (Elias, 2011). Nos centros urbanos, surgiram novos estabelecimentos comerciais agropecuários com a finalidade de atender aos agricultores, principalmente àqueles que produzem em escala, para servir de base ao processo 
de produção agrícola, com vendas de insumos, tais como: máquinas, implementos, equipamentos, corretivos de solos, fertilizantes, agroquímicos e sementes.

Nos centros urbanos, sem dúvida, existe um reordernamento do espaço a partir das atividades econômicas. Além da instalação das agroindústrias nas cidades e no campo, tem-se ainda uma nova configuração do comércio, especializado em atender à produção agropecuária, a partir dos interesses dos grupos econômicos, do Estado e do capital agroindustrial. Uma nova configuração nos centros urbanos desses municípios pode ser observada a partir do momento em que passam a se estruturar para atender às exigências do campo modernizado.

As atividades urbanas são dispostas e organizadas para atender às necessidades das atividades agropecuárias, ou seja, tem-se uma especialização das cidades para o atendimento das necessidades do campo. Sobre a questão, Elias (2012) afirma que, nas áreas de difusão do agronegócio, têm-se muitas demandas a partir da reestruturação produtiva. Essas provocam um aumento de várias atividades comerciais e de serviços especializados. Logo, a difusão do agronegócio amplia e reorganiza a produção material, tanto agropecuária quanto industrial, e determina a expansão quantitativa e qualitativa do comércio e dos serviços, sobretudo nos ramos ligados ao circuito superior da economia agrária. O setor terciário tem seu crescimento atribuído "ao crescimento da população e à revolução do consumo, este último erigido sob os auspícios do consumo de massa associado à existência individual e das famílias" (Elias, 2012, p. 7).

Na região, tanto os governos federal e estadual investiram em Pesquisa e Desenvolvimento (P\&D), principalmente pela EMBRAPA, sobretudo a partir do Centro de Pesquisa Agropecuária do Cerrado (CPAC), além da Empresa Goiana de Pesquisa Agropecuária (EMGOPA), objetivando o desenvolvimento de sementes e espécies de grãos adequadas aos solos da região (Goulart, 2012).

Além da ação estatal, diversos agentes locais, regionais e nacionais, contribuem para o desenvolvimento tecnológico dos municípios supramencionados, com base em projetos de investimentos científicos e tecnológicos em diversos produtos agrícolas, tais como: soja, milho, sorgo, algodão e arroz, por meio de instituições públicas e privadas prestadoras de serviços agropecuários ou não compuseram a nova configuração espacial urbana, a saber: a EMGOPA; a Universidade Federal de Goiás (UFG); a Universidade Estadual de Goiás (UEG); a Universidade de Rio Verde (UniRv); os Institutos Federais (IFs) (escolas agrícolas) - atual Instituto Federal Goiano (IF Goiano) e o Instituto Federal de Goiás (IFG), com cursos e pesquisas voltadas para a área agropecuária; e empresas de venda de insumos que prestam serviços de assistência técnica ao agropecuarista; laboratórios para fornecer análises laboratoriais, principalmente de solos, água, folhas, adubos e corretivos agrícolas etc.

Nas últimas décadas, a territorialização do capital tem se intensificado ainda mais com a instalação de empresas multinacionais do ramo agroindustrial, atraídas pelos incentivos do Estado e pela modernização constante, favorecendo o acúmulo do capital. Sobre a questão, Elias (2012, p. 10) destaca que o que distingue uma cidade do agronegócio de outro espaço urbano é "justamente uma hegemonia das funções inerentes às redes agroindustriais sobre as demais funções urbanas".

Assim, grandes agroindústrias de armazenamento, processamento e comercialização de grãos, cana-de-açúcar e carnes multinacionais e brasileiras (Louis Dreyfus, NESTLÉ, COMIGO, BRF Brasil Agroindustrial, Gradual, Granol, COMIVA, Cargil Agrícola S/A, Caramuru, Granol, Comiva ADM, Bunge, Marfrig, Frigoestrela, Raízen e BRF Brasil) mantêm ativos instalados na região sudoeste do estado de Goiás. Essas empresas se territorializaram no sudoeste de Goiás, dada a quantidade da produção de commodities agrícolas em alguns municípios dessa microrregião.

Para Oliveira (2008), ADM, Cargill, Bunge e Louis Dreyfus são as quatro maiores empresas controladoras de grãos em nível mundial e fazem parte do conjunto das principais empresas mundiais voltadas para a produção de alimentos. Essas empresas são resultados da criação dos monopólios mundiais de alimentos, frutos da mundialização do capital, uma vez que 
deixaram se der apenas empresas internacionais para se transformarem em multinacionais, não importando sua origem, se nacional ou estrangeira.

Fernandes (2008, p. 22), afirma que a apropriação territorial para a formação das cadeias produtivas é uma tendência globalizada das empresas, podendo ser de forma completa ou incompleta. Ela não ocorre tão somente no espaço rural, como também no urbano, pois, do ponto de vista institucional, as cadeias produtivas completas abarcam "a apropriação parcial ou total do fornecimento de insumos, da produção, do processamento, do comércio atacadista e do comércio varejista”. No Brasil, a apropriação completa de uma cadeia produtiva por uma determinada empresa é rara.

Para Castilho (2007, p. 39), essas empresas do agronegócio atuam antes, durante e depois da produção agropecuária e dominam cada vez mais o beneficiamento; a assistência técnica; o processamento agroindustrial; o mercado de fertilizantes e sementes; o armazenamento; o financiamento; a comercialização; e a exportação, detendo indústrias processadoras, armazéns e silos, empresas de comercialização de produtos, transporte, portos, centros de distribuição, escritórios ex portadores, etc.

A tecnificação do campo requereu um número maior de profissionais especializados, como, por exemplo, pilotos de aviões agrícolas, mecânicos especializados em modernas máquinas, e profissionais especialistas em cultivo de soja, milho, sorgo e cana-de-açúcar. Tal fato contribui para a chegada de novos cursos voltados para a área de Ciências Agrárias em Rio Verde e Jataí, o que, para Elias (2011), é uma migração descendente, ou seja, das cidades maiores para as cidades menores, resultado da necessidade de profissionais especializados para o agronegócio.

Após a consolidação da região sudoeste do estado de Goiás enquanto região produtora em escala, as distâncias foram diminuídas com a construção de infraestrutura de transporte e comunicação, fazendo com que aquela região fosse integrada ao circuito global de produção e consumo. Sob o viés da questão, Elias e Pequeno (2007, p. 26) destacam que, "cada vez que o território é reelaborado para atender à produção globalizada, superpõem-se novos fixos artificiais, aumentando a complexidade dos seus sistemas técnicos e de suas rugosidades".

Novas redes de transporte e comunicação foram construídas e estabelecidas na região sudoeste do estado de Goiás, ligando a região a lugares antes distantes e imprimindo novas relações entre os espaços. Pires (2008) afirma que aquela região tem seu desenvolvimento relacionado pelo desenvolvimento das vias rodoviárias, que conectou essa porção do território goiano à economia do Triângulo Mineiro e à economia paulista.

Como resultado, sobretudo, dos investimentos do Estado, a microrregião do sudoeste de Goiás é servida por eixos rodoviários fundamentais para o escoamento de grãos e das mercadorias para outras regiões do País. Entre as principais rodovias que compõe o eixo rodoviário da região, estão: a BR-060, que liga o sudoeste goiano a capital federal - Brasília, construída durante o Plano de Metas do Governo de Juscelino Kubitschek; a BR-158, que liga a região ao Estado de Mato Grosso; a BR-364, que liga a região às regiões Norte, Sudeste e Sul do País; e a BR-452 que liga a região ao município de Itumbiara, Goiás. As principais obras de infraestrutura realizadas na região foram construídas a partir de programas específicos para a região Centro-Oeste, desenvolvidos durante a execução do I Plano Nacional de Desenvolvimento (I PND) (Carmo; Guimarães; Azevedo, 2002).

Porém, a partir de 2007, os recursos advindos do Programa de Aceleração do Crescimento (PAC), contribuíram com a melhoria da infraestrutura dessa microrregião, sobretudo com grandes investimentos em logística do agronegócio, como o etanolduto, ferrovia norte-sul, máquina e equipamentos para estradas vicinais além da expansão na geração de energia, etc. Considerando que a logística é um dos principais elementos da cadeia do agronegócio brasileiro e requer uma logística diferenciada a fim de promover uma maior competitividade de seus produtos, foi um dos setores mais beneficiados com estes investimentos em infraestrutura logística que contribuiu para evitar gargalos no agronegócio.

Nas rodovias federais, estaduais e municipais da microrregião analisada, tem-se um intenso fluxo de caminhões graneleiros transportando grãos, óleo vegetal, biocombustível, leite resfriado, cana-de-açúcar, entre outros produtos, fazendo 
com que as rodovias de pista simples apresentem alguns trechos irregulares, resultando intenso fluxo de escoamento da produção agropecuária e que nem sempre recebem manutenção adequada. A BR-364 é responsável pelo escoamento da produção da região aos principais portos brasileiros, pois interliga Jataí ao porto goiano da Hidrovia Tietê-Paraná, em São Simão.

A hidrovia no Rio Paranaíba, na cidade de São Simão, Goiás, faz parte da Hidrovia Tietê-Paraná e exerce um importante papel como corredor de escoamento dos produtos agrícolas goianos, com destaque para os grãos. Uma parte considerável dos grãos produzidos na região sudoeste do estado de Goiás é via Hidrovia Paranaíba-Paraná-Tietê. O sistema hidroviário Paranaíba-Tietê-Paraná possui 2.400 quilômetros de vias navegáveis, com $1.642 \mathrm{~km}$ de vias principais e $758 \mathrm{~km}$ de vias secundárias.

A Ferrovia Norte Sul (FNS), também faz parte da infraestrutura da região sudoeste do estado de Goiás. Sua projeção vai do Município de Barcarena, estado do Pará, até o município de Rio Grande, Rio Grande do Sul, com 4.787 km de extensão, em bitola larga. Em território goiano, a FNS terá $991 \mathrm{~km}$ passando pelas regiões norte, central e sudoeste, nos municípios de Rio Verde e Santa Helena de Goiás.

A estrutura criada pelo agronegócio é complexa, compreendo a integração entre agricultura, indústria, conhecimentos e comercialização direta da produção, especialmente para a exportação (Roos, 2012). Segundo Calaça (2010), as estratégias do agronegócio compreendem também o monopólio da produção, distribuição e comercialização das sementes, dos insumos agrícolas e da genética animal.

\section{Considerações Finais}

Conclui-se que a abertura da fronteira agrícola nas terras goianas, a partir da década de 1940, resultou em inúmeras transformações no sudoeste de Goiás em função do relevo, do clima, do solo, mas também de significativo volume de investimentos, que tinha como objetivo, transformar suas terras altamente produtivas.

O investimento em tecnologia, ao mesmo tempo em que levou ao aumento da produtividade, provocou um significativo aumento do preço da terra, fazendo-a alcançar altos valores e expulsando os pequenos agricultores das áreas nobres de produção agropecuária, servidas de alta tecnologia de produção agropecuária.

Assim, a tecnologia passa a auxiliar o ritmo da produção agropecuária, que passa a ser cada vez mais moderna, com pivôs de irrigações; máquinas agrícolas utilizadas no preparo do solo, no plantio, nas pulverizações; galpões de armazenamentos; caminhões graneleiros e bitrens levando insumos a propriedades e produtos agrícolas às indústrias; e escritórios de acompanhamento em tempo real do preço dos produtos agropecuários no mercado internacional através das principais bolsas. Tudo em um processo contínuo, onde a instalação dos fixos passa a ter uma estratégia fundamental nos ganhos comerciais.

Alguns fatores influenciaram diretamente na transformação dos dois principais municípios do sudoeste de Goiás em áreas nobres do agronegócio goiano, a saber:

a) a proximidade das capitais federal e goiana e sua consequente onda de adensamento populacional, que contribui com melhorias na infraestrutura regional;

b) a modernização da agricultura regional, que favoreceu a aquisição de máquinas, construção de silos e armazéns, e agroindústria processadora de grãos e de carnes;

c) o baixo valor das terras da região durante a modernização agrícola, que favoreceu a chegada de imigrantes sulistas produtores de soja;

d) o desenvolvimento de tecnologias para a produção de soja em zonas tropicais;

e) a declividade do solo, favorável a mecanização agrícola; 
f) as condições físicas dos solos da região e regime pluviais adequados;

g) as melhorias no sistema de transporte regional composto por rodovias, ferrovias e hidrovias, e;

h) o papel do Estado através de vários programas governamentais e diversos incentivos fiscais que aumentou a área agropecuária e favoreceu a introdução de novas culturas, como, por exemplo, a soja e o milho;

Assim, os municípios de Jataí e Rio Verde, antes na periferia da produção em larga escala, se transformaram em líderes nacionais de produção de grãos, como soja e milho, e estrutura fundiária pautada na presença dos grandes estabelecimentos tecnificados e baixa mão de obra. A constituição destas grandes extensões de terras foi pautada em muitos casos a partir de conflitos agrários e desarticulação das relações de posse tradicional que existiam nestes municípios. Tais espaços onde, até então, a vida era comandada pelo tempo camponês passavam a sofrer as transformações da expansão do capital no campo, refletidas na cidade que, por sua vez, também se transformava. O ritmo citadino ali muda drasticamente com as transformações em curso e com a chegada de novos grupos capitalistas, já adaptados ao tempo do capital.

\section{Referências}

Antonello, I. T . (2011). Transformação socioespacial rural mediante a racionalidade capitalista no processo produtivo agrícola. Revista Campo - Território, v. 6, p. 53-74.

Barreto, C. de A. (2007). Agricultura e Meio Ambiente: percepções e práticas de sojicultores em Rio Verde- GO. 2007, 139p, Dissertação (Mestrado em Ciência Ambiental) - Universidade de São Paulo, São Paulo-SP.

Borges, R. E. (2012). Complexos agroindustriais e desenvolvimento regional: o caso do Sudoeste de Goiás. In: ENCONTRO NACIONAL DE GEOGRAFIA AGRÁRIA, 21., 2012. Anais...Uberlândia-MG: IG-UFU, p. 1-15.

Borges, R. E. (2006). No meio da soja, o brilho dos telhados: a implantação da Perdigão em Rio Verde (GO:, transformações e impactos socioeconomicos e espaciais. 2006. 210 f. Tese (Doutorado em Geografia) - Instituto de Geociências e Ciências Exatas, Universidade Estadual Paulista, Rio Claro.

Calaça, M., \& Dias, W. A. (2010). A Modernização do Campo no Cerrado e as Transformações Socioespaciais em Goiás. In: Campo-Território. v.5, n.10.

Canuto, A. (2004) Agronegócio: a modernização conservadora que gera exclusão pela produtividade. Revista NERA, Presidente Prudente, ano 7, n. 5, jul./dez. p. 1-12.

Carmo R. L. do, Guimarães, E., \& Azevedo A. M. M. de. (2002). Agroindústria, População e Ambiente no Sudoeste de Goiás. In: ambiente no Centro-Oeste. Campinas: Núcleos de Estudos de População/UNICAMP: PRONEX. Migrações e

Castilho, R. (2007). Agronegócio e Logística em Áreas de Cerrado: expressão da agricultura científica globalizada. Revista Anpege. v.3, p.33 a 43.

Cavalcante, M., \& Fernandes, B. M. (2008). Territorialização do agronegócio e concentração fundiária. Revista Nera, Presidente Prudente, v. 13, pp. 16-25.

Chaveiro, E. F. (2010). A urbanização do cerrado: espaços indomáveis, espaços deprimidos. Goiânia: Instituto de Estudos Sócio-Ambientais. Mimeografado.

Elias, Denise. (2005). Reestruturação produtiva da agropecuária e novas dinâmicas territoriais: a cidade do campo. In: ENCONTRO DE GEÓGRAFOS DA AMÉRICA LATINA, 10. Anais... San Pablo: USP.

Elias, Denise. (2011) Agronegócio e novas Regionalizações no Brasil. Revista Brasileira de Estudos Urbanos e Regionais, v. 13, n. 12, p. 153-170.

Elias, Denise. (2012). Relações Campo-Cidade, reestruturação urbana e regional no Brasil. In: Colóquio Internacional de Geocrítica,12. Anais...BOGOTÁ.

Elias, D. \& Pequeno, R. (2007). Desigualdades socioespaciais: nas cidades do agronegócio. Revista Brasileira de Estudos Urbanos e Regionais, Recife, v. 9, n. 1, p. 25-39, Maio.

Fernandes, B. M. (2008). Questão Agrária: conflitualidade e desenvolvimento territorial. In: Antonio Márcio Buainain (Editor). Luta pela Terra, Reforma Agrária e Gestão de Conflitos no Brasil. Editora Unicamp.

Fockink, E. R. (2007). Produção rural familiar em Jataí (GO): a Comunidade Rural da Onça. Dissertação de mestrado, Universidade Federal de Uberlândia. Uberlândia, MG: 2007. 147 p. CD-ROM.

Gonçales, C. (2003) "A Cooperativa Mista dos Produtores Rurais do Sudoeste Goiano Ltda (COMIGO) e o Desenvolvimento da Região de Rio Verde-GO." In: Pereira, Sebastião L; Xavier, C. L. (Orgs.) O agronegócio nas terras de Goiás. Uberlândia: EDUFU.

Goulart, G. T. (2012). Capital agroindustrial e economia regional: estudo sobre a organização produtiva da empresa Perdigão no sudoeste de Goiás e seus reflexos. Dissertação (mestrado em Economia). UFSC, Florianópolis-SC.

Graziano Neto, F. (1982). Questão agrária e ecologia:crítica da moderna agricultura. São Paulo: brasiliense. 
Guanziroli, C. E. (2006). Agronegócio no Brasil: perspectivas e limitações.Universidade Federal Fluminense, Faculdade de Economia, Texto para Discussão 186 , abril.

Guerra, L. de O. (2012). Estudo sobre o processo de desenvolvimento econômico de Rio Verde - GO. 77 f. Dissertação (Mestrado em Desenvolvimento Regional) - Faculdades Alves Faria, Goiânia.

Guimarães, G. M. A. (2010). Agronegócio, desenvolvimento e sustentabilidade: um estudo de caso em Rio Verde-GO. 2010.173 p. Tese de doutorado em Ciências Ambientais. Goiânia, Universidade Federal de Goiás.

Hespanhol, A. N. (2008). Modernização da Agricultura e desenvolvimento territorial. In: Encontro Nacional de Pesquisa, 4. Anais... São Paulo: ENGRUP. pp.370-392.

IBGE. (2011). Censo Demográfico, 2010. Características da população e dos domicílios: resultados do universo. Rio de Janeiro: IBGE.

IBGE. (2013). Produção Agrícola Municipal (PAM). Culturas Temporárias e Permanentes. Rio de Janeiro. Sistema de Informações SIDRA.

IBGE. (2019). Sistema IBGE de Recuperação Automática. População do Município de Rio Verde/GO. [online]. Rio Verde/GO.

IMB - Instituto Mauro Borges. (2003). Anuário Estatístico do Estado de Goiás-2003. Goiânia.

IMB - Instituto Mauro Borges. (2009). Ranking dos Municípios Goianos-2009. Goiânia.

IMB - Instituto Mauro Borges. (2011). Goiás em Dados-2011. Goiânia.

IMB - Instituto Mauro Borges. (2019). Dados Estatísticos. Goiânia.

IMB - Instituto Mauro Borges. (2021) Estatísticas Municipais. Goiânia.

Leal, C. A. A. (2006). Arapuca Armada: ação coletiva e práticas educativas na modernização agrícola do sudoeste goiano. Goiânia. Tese de Doutorado (Doutorado em Educação) - Faculdade de Educação, Universidade Federal de Goiás.

Martine, G. (1991). A trajetória da Modernização agrícola: A quem beneficia? In CEDEC, Lua Nova - Revista de Cultura e Política, Brasília-DF, n. 23, março.

Matos, P. F. de. \& Pessôa, V. L. S. (2009a). Territorialização da agricultura moderna na região da Estrada de Ferro (GO) e as modificações no espaço agrário. In: ENCONTRO NACIONAL DE GEOGRAFIA AGRÁRIA-ENGA, 19. Anais... São Paulo.

Matos, P. F. de. \& Pessôa, V. L. S. (2009b). Territorialização da agricultura moderna no Sudeste Goiano (Brasil): considerações preliminares. In: ENCONTRO DE GEOGRÁFOS DA AMÉRICA LATINA-EGAL, 12. Anais... Montivideo. p. 1-12.

Matos, P. F. de. \& Pessôa, V. L. S. (2009c). Territorialização da agricultura moderna no Sudeste Goiano: considerações preliminares. In: ANPEGE. Anais...Curitiba. ANPEGE.

Matos, P. F. de.; Pessôa, V. L. S. (2010). A Trama Socioespaciais do Agronegócio do Sudeste Goiano. In: ENCONTRO NACIONAL DE GEOGRAFOS, 16. Anais... Porto Alegre.

Mendonça, M. R. (2004). A urdidura espacial do capital e do trabalho no cerrado do Sudeste goiano. $448 \mathrm{f}$. Tese (Doutorado em Geografia) - Faculdade de Ciências e Tecnologia, UNESP, Presidente Prudente.

Mendonça, M. R. (2002). A Reestruturação do Capital e a Modernização da Agricultura no Sudeste de Goiás. Revista Pegada, V. 6. P. 02-16.

Oliveira, A. U. de. (2008). Territórios em disputa e agricultura. In: PAULINO, Eliane Tomiasi; Fabrini, João Edmilson (Org.). Campesinato e territórios em disputa. São Paulo: Expressão Popular.

Pedroso, Í. L. P. B.; Pedroso da Silva, Antenor Roberto. As transformações da agricultura do sudoeste de Goiás: da agropecuária extensiva a formação de cluster de grãos. In: CONGRESSO DA SOCIEDADE BRASILEIRA DE ECONOMIA E SOCIOLOGIA RURAL, 43. Ribeirão Preto. Anais... Ribeirão Preto: SOBER.

Pires, M. J. de S. (2005). As implicações do processo de modernização conservadora na estrutura e nas atividades agropecuárias da região centro-sul de Goiás. 2008. Tese (Doutorado em Desenvolvimento Econômico, Espaço e Meio Ambiente) - Instituto de Economia, Universidade Estadual de Campinas, Campinas/SP

Porto-Gonçalves, C. W. (2004). Geografia da riqueza, fome e meio ambiente: pequena contribuição crítica ao atual modelo agrário/agrícola de uso dos recursos naturais. In: Oliveira, A. U. de; Marques, Marta Inês Medeiros (org.). O campo no século XXI: território de vida, de luta e de construção da justiça social. São Paulo: Casa amarela; Paz e Terra. p. 27- 64.

Raffestin, C.(1993). Por uma Geografia do Poder. São Paulo: Ática.

Romanatto, E., Arriel, M. F. \& Lima, W. M. de. (2012). O Programa FOMENTAR/PRODUZIR - Informações e Análises para o Estado de Goiás e suas Microrregiões. Conjuntura Econômica Goiana, v. 22, p. 12-24.

Roos, D. (2012). A disputa pelo território: agricultura camponesa versus agronegócio nos assentamentos do centro-sul paranaense. In: JORNADA DO TRABALHO, 13. Anais... Presidente Prudente.

Scopel, I., Peixinho, D. M. \& Sousa, Marluce. (2005). S. A formação de areais e seu controle na região de Jataí e Serranópolis/GO. Relatório final do Projeto. Jataí/GO: PROINPE/SECTECGO. $155 \mathrm{f}$. 
Research, Society and Development, v. 10, n. 13, e153101320578, 2021

(CC BY 4.0) | ISSN 2525-3409 | DOI: http://dx.doi.org/10.33448/rsd-v10i13.20578

Silva, J. S. (2010). Considerações sobre a Ocupação do Cerrado na Microrregião do Sudoeste de Goiás: Modernização versus degradação. Rama: Revista em Agronegócio e Meio Ambiente, v. 1, p. 89-99.

Silva, A. G.da, \& Francischini, R. (2013). Sistemas de produção de milho safrinha em Goiás. In: SEMINÁRIO NACIONAL [DE] MILHO SAFRINHA, 12. Dourados. Anais... Brasília, DF: Embrapa; Dourados: Embrapa.

Silveira, M. R. da, \& Barreira, C. C. M. A.(2012). Municípios pequenos e deprimidos no sudoeste goiano: "os hipócritas roubam a cena". Campo - Território, v. 7, p. 169-187.

Sinhorini, J. M. \& Saquet, M.A. (2005). Territorialização da Cooperativa Agropecuária Capanema LTDA (COAGRO): uma articulação entre o local e o global. In: Simpósio Nacional de Geografia Agrária, 3., Simpósio Internacional de Geografia Agrária, 2. Anais... Presidente Prudente.

Vinhas, M. (1980). A Terra, o homem e as reformas. Rio de Janeiro, Edições Graal. 